\title{
ECONOMIC MIGRATION AND LABOUR TRAFFICKING FROM BULGARIA
}

\author{
Georgi Petrunov ${ }^{1}$
}

DOI: https://doi.org/10.31410/ITEMA.2019.7

\begin{abstract}
Economic migration from the post-socialist countries to the countries of Western Europe continues to be a highly dynamic process, with large migration flows marking the second decade of the 21 st century. Bulgaria is no exception to this trend: thousands of Bulgarians each year migrate to Western European countries. In search of well-paying jobs and a better life, some of them find themselves trapped in trafficking schemes and fall victim to the modern form of slavery. This report explores trafficking in human beings from Bulgaria to Western Europe, and in particular trafficking for the purpose of labor exploitation. The research methods used include court case analysis and in-depth interviews with prosecutors, investigators, police officers, NGO representatives and victims of trafficking. The report examines the main reasons for involvement in labor trafficking, typical trafficking practices, recruitment methods, and the various forms and economic sectors in which the victims are exploited. Among the key factors for migration and labor trafficking the research highlights weak and slow economic development, high levels of poverty and social exclusion coupled with the marginalization of social groups, lack of adequate work and job insecurity, and high levels of crime.
\end{abstract}

Keywords: Economic disparities, Crime, Exploitation

\section{INTRODUCTION}

$\mathrm{T}$ he twenty-first century, as Anna Krasteva (Krasteva, 2014) points out, has been metaphorically described by researchers as the ,age of peoples on the move”, the ,era of migration”, and the ,migration planet”. Although migration is not a new phenomenon, one can argue that it has become one of the main features of the modern world and the trend is a steady increase of the international migrant stock. The United Nations (UN, 2019) estimate that in 2019, there are 271,642,105 migrants in the world, which is almost 120 million more than in 1990, when the number of migrants was $153,011,473$. This means that in $2019,3.5 \%$ of the world's population are migrants.

The multiple complex motivations and migration trajectories often combine economic, social and political factors (Manning, 2013). Nevertheless, with the exception of periods of war, ethnic or religious conflict, international movement is mostly economically motivated (Moch, 2013). People from less developed countries are seeking opportunities for a better life for themselves and their families in economically advanced countries, where they can find more jobs and higher incomes than in their home country. Economic globalization and modern technologies make the economic and social disparities between nations even more visible (Barner, Okech, \& Camp, 2014). According to some authors, the access to information about the conditions of life in rich countries, as well as the easier contact with friends who have already gone abroad deepens the perception of inequality and lack of prospects at home, motivating people from poorer countries to migrate to richer countries (Jac-Kucharski, 2012; Cho, 2015; Mo, 2018). 
As elaborated by Saskia Sassen (Sassen, 2002), with economic globalization various cross-border circuits emerge, that have become a source for livelihood, accumulation of profits and foreign currency in many countries around the world. These chains are specifically developed to generate big profits, but at the expense of disadvantaged people. They include cross-border migration and trafficking in human beings, and the exploitation of workers in formal and informal labor markets.

This report deals specifically with trafficking in human beings for the purpose of labor exploitation. In particular, the paper analyzes the main aspects of this type of trafficking of Bulgarians in Western European countries. The report draws upon sources and data collected through a project funded by the University of National and World Economy, and includes desk research of court cases and in-depth interviews with prosecutors, investigators, police officers, NGO representatives and victims of trafficking.

\section{CONDITIONS FOR THE DEVELOPMENT OF LABOUR TRAFFICKING FROM BULGARIA}

Scholars (Barner, Okech, \& Camp, 2014) draw attention to the development of criminal markets, both between "developed" and "peripheral" countries, and in "peripheral"/developing nations themselves - such as trafficking in humans. Bulgaria belongs to the so-called developing countries, which after the fall of the communist regime in 1989 underwent radical changes in the political, economic and social spheres. The country's post-communist period is marked by multiple economic and political crises. Furthermore, the enforcement of public policies of de-industrialization, deregulation, privatization, decentralization, and liberalization simultaneously in key spheres - the social security system, health care and education, local government and transport, in infrastructure and public services (electricity, water, etc.), in the labor market, etc., lead to the impoverishment and marginalization of large groups of people (Jeliazkova, 2011).

During the last ten years, the economic indicators in Bulgaria have improved. The GDP has increased, unemployment levels have dropped, and the average monthly salary has risen. Nevertheless, Bulgaria remains the country with the lowest per capita GDP in the European Union (6,550 euro in 2018 compared with an EU 28 average of 28,270 euro $)^{2}$, and with the highest percentages of people at risk of poverty or social exclusion $\left(32,8 \%{ }^{3}\right.$ in 2018). Although the average salary has increased, almost $80 \%$ of the workers in 2017 are paid below that and more than half of the workers have official incomes below the minimum wage (Ministry of Finance, 2017). There are great wage differences between regions: according to data of the National Statistical Institute $^{4}$ while in southwestern Bulgaria (which includes the capital Sofia), the average gross monthly salary reaches 700 euros, in the cities of the Northwestern Region (ranked second in the EU for low purchasing power of the population) the average gross salary is around 400 euro. Disparities like this are a strong push factor for migration - both internal and external.

Bulgaria is a source country of migration. Official statistics ${ }^{5}$ show that in 2018 only, 33,225 people emigrated from Bulgaria. This is the official number of people who have declared their change of residence; the figure does not take into account seasonal migrants and those who have

Eurostat, Real GDP per capita, code [SDG_08_10].

Eurostat, People at risk of poverty or social exclusion, code [T2020_50].

National Statistical Institute, Average Gross Monthly Salary in 2019, available at: https://www.nsi.bg/bg/ content/, accessed on 28.10.2019

$5 \quad$ National Statistical Institute, External migration by age and gender, available at: http://www.nsi.bg/bg/ content/3072/, accessed on 28.10 .2019 
not declared they were living abroad. According to experts, the number of Bulgarians who have emigrated since the 1990s is nearly 2 million (Jeliazkova et al, 2018). Other scholars point out that for $90-95 \%$ of the Bulgarian emigrants who left the country in large numbers between 2000 and 2003, the main incentive was the opportunity to earn $€ 15-20,000$ per year, compared with a typical annual salary of $€ 1,000-2,000$ for unskilled labor in Bulgaria; many of the emigrants work in the lowest segment of the West European labor market (Bezlov et al., 2007, p. 128). A recent study shows that among low-qualified Bulgarians, the wage levels for the same work are much higher in Western Europe than in Bulgaria, which motivates people to look for employment abroad (Stoilova \& Dimitrova, 2017).

The circumstances of large groups of people in poor socio-economic conditions who are looking for a better life offer criminals a new niche, especially after the bans for free movement within the EU were lifted. People living in poverty are more likely to accept risky job offers abroad or to fall victims of exploitation by traffickers without being able to seek help. The Eastern European countries, including Bulgaria, are among the most affected by human trafficking and the main countries of origin of victims of trafficking to richer countries, mainly in Western Europe (Mattar, 2009; Shelley, 2014; UNODC, 2018). According to Europol (2016), most of the reported victims are Bulgarians, along with citizens of the Czech Republic, Estonia, Poland, Romania, and Slovakia. According to the UNODC (2018) report, 33\% of the identified victims of trafficking in the countries of Western and Southern Europe come from Southeast European countries.

The living conditions in Bulgaria and the strong desire of people to migrate, motivated by the search for a better standard of living abroad, create a fertile ground for the operations of traffickers who thus respond to the demands of exploitative employers for cheap labor (Mansoor \& Quillin, 2006; Mahmoud \& Trebesch, 2010). The exploitation of victims of trafficking ranges from sexual exploitation, forced labor, to begging and organ harvesting (Petrunov, 2014). The next section of the report focuses on trafficking for labor exploitation.

\section{ASPECTS OF LABOR TRAFFICKING FROM BULGARIA}

In Bulgarian law, ${ }^{6}$ trafficking in human beings is defined as: "the recruitment, transportation, transfer, harbouring or admission of persons, regardless of their will, through the use of coercion, abduction, unlawful imprisonment, deception, abuse of power, abuse of vulnerability, or by giving, receiving or promising benefits, to obtain the consent of a person having control over another person when exercised for the purpose of exploitation." According to the ILO Forced Labour Convention from 1930, labor exploitation constitutes "all work or service which is exacted from any person under the menace of any penalty and for which the said person has not offered himself voluntarily." The prohibition of forced labor relates to all types of work, services and employment, regardless of industry or profession, whether the practice is legal and formal, or illegal and informal in nature. The crime of labor exploitation involves practices such as slavery or those similar to slavery, debt bondage and servitude (Europol, 2016).

The main destination countries of trafficking in human beings from Bulgaria are the Czech Republic, Greece, Italy, Spain, Cyprus, but cases of forced labor involving Bulgarians are found in Sweden, Norway, Germany, the United Kingdom, the Netherlands, Portugal and other Western European countries. The analysis of the identified cases indicates that the most vulnerable group for this type of trafficking are young to middle-aged men and women with low education

Cf. The Law on Trafficking in Human Beings in Bulgaria. 
and qualifications, who do not have a well-paid job in Bulgaria or work in seasonal employment. Most often, the recruiter is not the same as the exploiter himself; to recruit victims, the recruiter publishes advertisements in media or relies on personal contacts in certain communities. Similar conclusions are found in the Europol report (2016): victims are lured through word of mouth and online advertisements, posted on social media and on specific websites (e.g., online recruitment agencies). In one of the court cases investigated, traffickers recruited victims directly in the Employment Office in one city in northwestern Bulgaria, promising the unemployed lucrative jobs in Western Europe; however, on arrival at the final destination they were exploited. A man who worked in Greece shares: "I found out from acquaintances that they may introduce me to a person who arranges fruit-picking work in Greece... [He] offered me a good salary, promised to take care of the paper work, even to drive me [there]. I agreed... we went with his van and picked up other people along the way... When we arrived, we found ourselves in hell." Upon arrival in Greece, he finds himself a victim of labor trafficking; his documents were taken by the traffickers, he was not free to travel, and had to work at different places each day, but never received the agreed payment for the harvested produce.

Transportation in many of these cases is legal, with no resistance from victims, as they are convinced that they will work abroad under pre-arranged conditions. After arriving in the country of final destination, the victims realize that the conditions are completely different from what they have been promised in advance - both in terms of living and working conditions. One of the respondents traveled to Sweden after an acquaintance offered him a job as an elderly caregiver. Upon arrival, he was taken to the outskirts of the city and accommodated with another Bulgarian in a tent, located in a wooded area - without sewage, without electricity, with food brought by the trafficker from time to time: "I didn't know where I was or how to get to the city ... It was scary, you don't know what might happen, a dungeon everywhere." Regarding the work, the respondent realizes he has been deceived: "I did not become a caregiver. They lied to me. [The trafficker] made us carry the beams and metal for a cottage in the forest. They were building it; we were just laborers. [He] said, let's get the job done here first, then he'd arrange for us work as caregivers. And that was a lie, it was clear."

The sectors in which Bulgarian men and women are exploited are most often agriculture, harvesting of fruits/vegetables and the food industry; women are exploited as seamstresses or domestic helpers, and men in construction and logging. Usually the victims work from morning till night, with little or no breaks. The victims who were interviewed stated that they were forced to work between 10 to 14 hours a day, six to seven days a week. A young woman who worked in Germany says: "It was hard [picking strawberries] work, you squatted most of the time, but that wasn't the problem. The bad thing is that they made us work 10-11 hours with two breaks of 20 minutes each. We rarely drank water and there was almost no time to eat. Considering that we worked without a day off sometimes, after a week you felt like dying. You can't get a good night's sleep, [it was] very bad." The pay is well below what was agreed. The interviews show that almost all of the employees got money withheld from the workers' wages for shelter, food (though only once a day), for arranging the paperwork and transportation. After covering these and other daily expenses, there is hardly any money left for the workers - in some cases they do not have enough to buy a ticket to return home. In many cases, the exploiters tell victims that they'll be paid at the end of the season, forcing them to stay if they want to get anything at all.

Information gathered from court documents shows that this type of trafficking is most often organized by small groups, often with family ties between the members who have established 
networks of contacts in the countries of destination. Group leaders and their confidants usually reside in the destination country and control the victims. The main means of control in trafficking for forced labor include threats that if the victim leaves, they will not receive any money; constant surveillance during work; taking the victims' personal documents; threats to inform local authorities that the victim is residing and working illegally. In many cases, victims are also controlled by the debt they have accumulated (typically, the money borrowed to travel to the country of destination and the cost of staying). In some cases, traffickers also use physical violence.

\section{CONCLUSION}

The study shows that among the key factors for migration and labor trafficking are weak and slow economic development, associated with huge economic inequalities between regions and countries; high levels of poverty and social exclusion coupled with the marginalization of social groups; lack of adequate work and job insecurity; high levels of crime. Notwithstanding the fact that there will always be poorer and richer countries, that the free movement of people cannot and should not be restricted, that the pursuit of wellbeing should not be denied anyone, one question remains open: How to make this movement safer? In this respect further analysis and identification of the most vulnerable groups is needed, along with identification of the measures to improve their situation first in their home country. We also need to examine more rigorously the factors behind the increase in the number of people being trafficked and how these factors can be eliminated or at least mitigated.

These issues relate to the so-called supply side of trafficking; on the other side is the demand for the services offered by traffickers through the exploitation of their victims. Therefore, the demand side must necessarily be included in the formula to mitigate the severity of the problem and to reduce its scale. As long as in destination countries employers go unpunished for using cheap labor by violating not only labor but also human rights, no adequate response to the issues can be expected. Only the close collaboration of all stakeholders, including researchers, experts from civil society organizations, social workers, law enforcement officials and government agencies, can ensure that the problems are properly addressed and the policies for prevention and combating trafficking in human beings and the measures implemented are based on knowledge and best practices.

\section{ACKNOWLEDGMENT}

This paper is result of the author's work in frame of research project № NID NI-10/2018: "Money Laundering from Human trafficking" financed by University of National and World Economy, Sofia.

\section{REFERENCES}

Barner, J., Okech, D., \& Camp, M. (2014). Socio-economic inequality, human trafficking, and the global slave trade. Societies, 4, 148-160; https://doi:10.3390/soc4020148.

Bezlov, T., Gounev, P., Petrunov, G., Tzenkov, E., \& Tzvetkova, M. (2007). Organized crime in Bulgaria: Markets and trends. Sofia: Center for the Study of Democracy.

Cho, S.Y. (2015). Modeling for Determinants of Human Trafficking: An Empirical Analysis. Social Inclusion, 3, 2-21 (Special Issue „Perspectives on Human Trafficking and Modern Forms of Slavery"). http://dx.doi.org/10.2139/ssrn.2117838. 
Europol. (2016). Trafficking in human beings in the EU. Hague: Europol Public Information. Jac-Kucharski, A. (2012). The Determinants of Human Trafficking: A US Case Study. International migration, 50(6), 150-165. https://doi.org/10.1111/j.1468-2435.2012.00777.

Jeliazkova, M. (2011). Inequality and policies. Trojan: Alja (in Bulgarian).

Jeliazkova, M., Minev, D., Draganov, Dr., Krasteva, V. \& Stoilov, A. (2018). Youth employment policies in Bulgaria. Tallinn: Tallinn University. Retrieved from: http://www.except-project.eu/working-papers/.

Krasteva, A. (2014). From migration to mobility: Policies and routes. Sofia: New Bulgarian University Publishing House (in Bulgarian).

Mahmoud, T.O., \& Trebesch, C. (2010). The economics of human trafficking and labour migration: Micro-evidence from Eastern Europe. Journal of Comparative Economics, 38(2), 173-88. https://doi:10.1016/j.jce.2010.02.001.

Manning, P. (2013). Migration in world history. Abingdon: Routledge.

Mansoor, A., \& Quillin, B. (2006). Migration and Remittances: Eastern Europe and the Former Soviet Union. Washington, DC: World Bank.

Mattar, M. (2009). Trafficking in persons: Global overview, current trends, and pathways forward. Washington, DC: John Hopkins University.

Ministry of finance. (2018). Data provided by Ministry of finance in response to a question from the Member of Parliament Jelio Boichev. Retrieved from: https://www.parliament.bg/pub/ PK/318729854-06-1098.pdf.

Mo, C.H. (2018). Perceived relative deprivation and risk: An aspiration-based model of human trafficking vulnerability. Political behavior, 40(1), 247-277. https://doi:10.1007/s11109-0179401-0.

Moch, L. P. (2013). Lessons and cautionary tales from the past: Building bridges from migration history to Europeanness. National Identities, 15(1), 9-19. https://doi:10.1080/14608944.201 2.733151 .

Petrunov, G. (2014). Human trafficking in Eastern Europe: The case of Bulgaria. The Annals of the American Academy of Political and Social Science, 653(1), 162-182. https:// doi:10.1177/0002716214521556.

Sassen, S. (2002). Women's burden: Counter-geographies of globalization and the feminization of survival. Nordic Journal of International Law, 71(2):255-274. https:// doi:10.1163/157181002761931378.

Shelley, L. (2010). Human trafficking: A global perspective. New York: Cambridge University Press;

Stoilova, R. \& Dimitrova, E. (2017). Emigration from the Perspective of School to Work Transition in Bulgaria. Czech Sociological Review, 53(6), 903-933. https://doi:10.13060/00380 288.2017.53.6.380

United Nations. (2019). Workbook: UN Migrant stock total 2019. United Nations, Department of Economic and Social Affairs, Population Division. Retrieved from: https://www.un.org/ en/development/desa/population/migration/data/estimates2/estimates19.asp

UNODC. (2018). Global report on trafficking in persons 2018. New York: United Nations. 